\title{
The Turkey-EU-US Triangle in Perspective: Transformation or Continuity?
}

Author(s): Ziya Önis and Suhnaz Yilmaz

Source: Middle East Journal, Vol. 59, No. 2, Changing Geopolitics (Spring, 2005), pp. 265284

Published by: Middle East Institute

Stable URL: http://www.jstor.org/stable/4330128

Accessed: 13-06-2017 11:10 UTC

JSTOR is a not-for-profit service that helps scholars, researchers, and students discover, use, and build upon a wide range of content in a trusted digital archive. We use information technology and tools to increase productivity and facilitate new forms of scholarship. For more information about JSTOR, please contact support@jstor.org.

Your use of the JSTOR archive indicates your acceptance of the Terms \& Conditions of Use, available at http://about.jstor.org/terms

Middle East Institute is collaborating with JSTOR to digitize, preserve and extend access to Middle East Journal 


\title{
The Turkey-EU-US Triangle in Perspective: Transformation or Continuity?
}

\author{
Ziya Önis and Suhnaz Yilmaz
}

This article examines the delicate dynamics of the triangle of Turkey-EU-US relations. While acknowledging the role of the United States in promoting close links between Turkey and the EU, this study underlines the limits of American influence on EU decision-making on issues concerning "deep integration." In this context, the future of this triangular relation depends on the interplay of contending forces in Turkey's domestic political arena as well as the dynamics of trans-Atlantic relations in the international scene.

$\mathbf{T}$

he first major war of the $21^{\text {st }}$ century lasted only 21 days. Yet the US invasion of Iraq left a tremendous mark not only in Iraq and the volatile Middle East, but also intensified the already emerging trans-Atlantic rift and set the Turkish-American alliance on a troublesome path. The military victory came rather quickly for the United States. However, translating military victory into a political one and achieving longterm peace and stability, as well as restoring the delicate balance of the TurkeyEuropean Union-US triangle proves to be a much more challenging task for all the parties concerned.

Turkey had been an important ally of the United States throughout the Cold War era. With the end of the Cold War and the absence of the Soviet threat, Turkey's geostrategic importance came under increasing scrutiny. After a temporary interlude in the early 1990s, however, the strategic partnership between the two countries was restored on a new basis. Yet, Turkish-American relations came under severe challenge during the early months of 2003 in the context of the War in Iraq, following the failure of the Turkish Parliament on March 1 to authorize the deployment of US troops to Iraq via Turkish territory. Clearly, this was interpreted as a major blow by the Bush Administration, resulting in a serious setback in the long-standing TurkishAmerican partnership. What is interesting for our purposes is the impact of this rupture in Turkish-US relations on Turkey's relations with the European Union. The relevance of this question increases at a time when the Iraq War has resulted in a massive rift in the trans-Atlantic alliance as well as generating deep divisions within the "New Europe" itself.

This article makes the following main arguments. First, the role of the United

The authors are Professor and Assistant Professor respectively, Department of International Relations, Koç University, Istanbul, Turkey. Valuable comments on an earlier draft by Kemal Kirisçi, Umut Korkut , Soli Özel and Sabri Sayari and the able assistance of Gamze Sezer are gratefully acknowledged. 
States in promoting closer links between Turkey and the EU, both historically and in the more recent context, has indeed been critical. Yet, one also needs to recognize the limits to American influence on the EU in decisions concerning "deep integration." This became particularly evident in the context of the Copenhagen summit of December 2002, when explicit pressure by the Bush Administration in support of accelerated progress for Turkish membership appeared to have backfired. Second, the war on Iraq has pushed Turkey closer to the EU and accelerated the reform process on the economic and democratization fronts in line with the EU's Copenhagen criteria. In retrospect, the war has helped to tilt the balance of power within Turkey's domestic politics further in the direction of the "pro-EU coalition" which had already been gathering strength particularly since the Helsinki decision of 1999 granting Turkey candidate status. Moreover, the more credible set of incentives from the EU since the Helsinki summit, in addition to giving momentum to Turkey's transition from a procedural to substantive democracy and helping to transform its economy, also gave way to a closer alignment of Turkey's foreign policy with the major European powers leading to a relative "Europeanization" of Turkish foreign policy. Finally, the fact that short-term dynamics appear to favor closer relations between Turkey and the EU should not lead to the misleading interpretation that Turkey would be able to achieve smooth and rapid progress towards EU membership in the absence of US support. While in the December 2004 summit the EU had set a date to start the accession negotiations with Turkey, the thorny path towards Turkey's full membership is still full of difficulties and uncertainties. In this long and arduous journey, maintaining US support would be an important asset for Turkey particularly on critical issues such as Cyprus.

Hence, it is vitally important from a Turkish perspective that the partnership with the US be restored and placed on a sound footing. This is also important for the future course of Turkey-EU relations. Indeed, we argue that the restoration and further deepening of the Turkey-EU-US triangle is of overriding importance. Not only will closer relations with the US continue to assist Turkey's quest for EU membership, but also Turkey, not as an isolated state but as a member of the EU, will be in a far more advantageous position in developing a more balanced relationship with the United States. This, in turn, will enable Turkey to protect its national interests better and to play a more constructive role in the wider Middle East as a "benign regional power." In this respect, a "benign regional power" differentiates itself from a "coercive regional power" in the sense that the latter is much more likely to resort to force to exert its influence in the surrounding region.

Finally, the temporary setback in Turkey-US relations can be overcome and the triangular relationship involving Turkey, the EU and the US can be reconstituted on a stronger basis. Yet, this optimistic assessment should be qualified by the fact that serious challenges need to be tackled both with respect to Turkey's relations with the EU and the US. Moreover, there is a need to replenish the reservoirs of trust on all sides. The passive "wait and see" attitude based on the vague notion of "geo-strategic importance" will not be very helpful in this context. What is required is an active strategy designed to improve relations with the EU and the US simultaneously. Yet, the ability to develop and activate such a strategy depends critically on the interplay 
of contending forces in Turkey's domestic political arena and the dynamics of the trans-Atlantic relations in the international scene.

\section{TURKEY AT THE GATES OF EUROPE: SIGNIFICANCE OF THE COPENHAGEN SUMMIT}

The roots of Turkey's long march toward Europe predate the Republican period and may be traced back to the Ottoman times. European orientation meant Westernization, enlightenment and a move towards modernity. In formal terms, Turkey, together with Greece, was one of the first countries to develop relations with the emerging European Community (EC) in the early 1960s, signing an associate agreement in 1963. ' Yet, Turkey's relationship with the Community did not follow a smooth trajectory. The Community has for a long time been unreceptive to Turkey's full membership on the grounds of the country's size, level of development and its predominantly Muslim identity. ${ }^{2}$ It is fair to say that the EU in the 1990 s was far more receptive to incorporation of post-Communist states such as Poland and Hungary into its orbit, because these countries did not pose the kind of boundary questions for Europe that the Turkish membership appeared to entail. ${ }^{3}$ For the EC/EU in the 1980 s and the 1990s, Turkey, rather than being a "natural insider", was an "important outsider" with whom relations ought to be developed on an arm's length basis barring full integration.

Turkey's domestic politics did not help in this respect either. In retrospect, the failure to convert the military intervention in Cyprus in 1974 to an internationally acceptable political settlement has proved to be rather costly for Turkey's fortunes involving relations with Europe. Indeed, the Cyprus intervention set into motion a series of forces leading to the democratization and subsequent membership of Greece to the EC in 1981. With Greece as a full-member of the Community and given the nature of the bilateral conflicts outstanding between the two countries, Turkey's relations with Europe experienced a setback. It would be unfair, however, to attribute negative developments from a Turkish perspective solely to the Greek veto which continued until 1999.

Ironically, at the time of Greek accession, Turkey experienced one of the periodic collapses of its democratic regime, at which point relations with the Community

1. The history of Turkey-EU relations has been extensively investigated. See among others, Heinz Kramer, A Changing Turkey: The Challenge to Europe and the United States (Washington, DC: Brookings Institution Press, 2000); William Hale, Turkish Foreign Policy, 1774-2000 (London; Portland, OR: Frank Cass, 2000); Attila Eralp, ed., Türkiye ve Avrupa: Batililasma, Kalkinma ve Demokrasi [Turkey and Europe: Westernization, Development and Democracy], (Ankara: Imge Kitabevi Yayinlari, 1997).

2. See, in this context, Ziya Önis "An Awkward Partnership: Turkey's Relations with the European Union in Comparative-Historical Perspective," Journal of European Integration History, Vol. 7, No. 1, 2001, pp. 105-119.

3. For a detailed comparison of Polish and Turkish experiences, see, Ziya Önis, "Domestic Politics, Transnational Influences and the Impetus for Reform: The Diverse Paths of Poland and Turkey on the Road to EU Membership," available online at http://home.ku.edu.tr/ zonis/publications.html. 
reached the lowest point in post-War history. By the time that Turkey returned to formal democracy and applied for full-membership in 1987, it was confronted with a changed Europe. The New Europe was an entity which placed far more emphasis than in the past on the quality of democracy and the achievement of civil and human rights. ${ }^{4}$ Although Turkey, as a typical example of "second wave democracy," has enjoyed formal democracy, albeit with temporary interruptions, since 1950, its democratic credentials judged on the basis of "substantive democracy" fell rather short of the standards required by the "New Europe" of the late twentieth century. Furthermore, the severe identity challenges represented by the emergence of militant Kurdish nationalism and the rise of political Islam have created serious strains on the Turkish political system. ${ }^{5}$ The failure to incorporate these divisive elements peacefully into the democratic system has been synonymous with slow progress in relations with Europe. Rejection of membership application, at a time when the Community was prepared to embrace former Communist countries in Eastern Europe, provided few incentives for peaceful or democratic resolution of Turkey's perennial identity conflicts. On a positive note, relations with Europe continued to develop, although at a rather gradual pace. The Customs Union Agreement that came into effect at the end of 1995 was an important turning point in this respect.

Nevertheless, judged by the standards of full-membership, the Customs Union failed to provide the mix of conditions and incentives required for a comprehensive transformation of Turkey's economic and political system.

Turkish aspirations for membership experienced a serious setback in the EU's Luxembourg Summit of December 1997 when Turkey was denied candidate country status. This produced a major nationalist backlash, which was also reflected in the general elections of April where two nationalistic parties emerged as the principal winners and the principal coalition partners during the 1999-2002 period. ${ }^{6}$ Two years later, however, Turkey was offered the prospect of full-membership at the Helsinki Summit and this proved to be a landmark in Turkey-EU relations. The reasons underlying the reversal of the Luxembourg decision are manifold and have been docu-

4. See Kramer, A Changing Turkey, and Hale, Turkish Foreign Policy, as well as, Meltem MüftuilerBaç, Turkey's Relation with A Changing Europe (Manchester: Manchester University Press, 1997) in this context.

5. On the nature of Turkish democracy and its limitations, see Ergun Özbudun, Contemporary Turkish Politics: Challenges to Democratic Consolidation (Boulder, Colo: Lynne Rienner Publishers, 2000); Fuat Keyman, Türkiye ve Radikal Demokrasi [Turkey and Radical Democracy], (Istanbul: Baglam Yayinlari, 1999).

6. The main coalition partners were the left-nationalist "Democratic Left Party" (the DSP) and the ultra-nationalist "Nationalist Action Party" (the MHP). It is fair to say that only the minor partner in the coalition government, "The Motherland Party" (the ANAP) had an unambiguous pro-EU orientation in terms of commitment to political and economic reforms. 
mented elsewhere. ${ }^{7}$ Clearly several factors were at work ranging from American influence to the social democratic wave in Europe with its emphasis on multi-culturalism. The deepening of the democratization process in Greece following nearly decades of EU membership was reflected in its attempts to solve problems with Turkey through negotiation and compromise within the EU framework as opposed to direct confrontation. Similarly, countries like Britain that preferred a looser pattern of integration appeared to favor Turkish membership. Finally, the lobbying activities of the Turkish business community in Brussels, notably through its associations like TÜSIAD ${ }^{8}$ also exercised influence.

Following the Helsinki Summit, the institutionalized process of interaction initiated with the EU, precipitated a series of major changes in Turkish domestic politics from early 2000 onwards. A series of major political reforms took place, involving the extension of cultural rights for minorities to the elimination of the death penalty altogether in August. ${ }^{9}$ The severe economic crisis that the Turkish economy experienced in late 2000 and early 2001 were also instrumental in breaking down the resistance of anti-reformist elements and accelerating the momentum of the reform process. The prospect of EU membership and the material benefits that it promised appeared all the more attractive at a time of a deep economic crisis.

Important developments continued to take place towards the end of 2002. A major development concerned the massive electoral victory of the Justice and Development Party (the AKP), putting an end to the era of highly unstable coalition politics of the 1990s. The AKP, with its Islamist roots but allegedly moderate credentials, appeared to be more committed to the task of EU membership than any of its predecessors, not merely as a vague principle but as a commitment to satisfy the associated conditions. ${ }^{10}$ Indeed, the victory of moderate Islamists in Turkey was widely wel-

7. See Ziya Önis, "Luxembourg, Helsinki and Beyond: Towards an Interpretation of Recent TurkeyEU Relations," Government and Opposition, Vol. 35, No. 4, Autumn 2000, pp. 463-483; Chris Rumford, "From Luxembourg to Helsinki: Turkey, the Politics of EU Enlargement and the Prospects for Accession," Contemporary Politics, Vol. 6, No. 4, December 2000, pp. 331-343; William Park, "Turkey's European Union Candidacy: From Luxembourg to Helsinki to Ankara?," Mediterranean Politics, Vol.5, No.3, Autumn 2000, pp. 31-53.

8. TÜSIAD stands for “Turkish Industrialists' and Businessmen's Association." As an influential organization of "big business" in Turkey, TÜSIAD has been particularly vocal in its demands for economic and political reforms and has been actively lobbying for Turkish membership in Brussels.

9. For the details of these dramatic developments on the domestic front, see Ziya Önis, "Domestic politics, International Norms and Challenges to the State: Turkey-EU Relations in the Post-Helsinki Era," Turkish Studies, Vol. 4, No. 1, 2003, pp. 9-35.

10. On the elections of November 2002 and the rise of AKP see Ziya Önis and Fuat Keyman, "Turkey at the Polls: A New Path is Emerging," Journal of Democracy Vol. 14, No. 2, April 2003, pp.95107, to be reprinted in Larry Diamond, Marc F. Plattner and Daniel Brumberg, eds., Islam and Democracy in the Middle East (Baltimore: Johns Hopkins University Press, 2003, forthcoming); Soli Özel, "After the Tsunami," Journal of Democracy, Vol. 14, No. 2, April 2003, pp.80-94, as well as Soner Çagatay, “The November 2002 Elections and Turkey's New Political Era" and Ali Çarkoglu, "Turkey's November 2002 Elections: A New Beginning?,'both in Middle East Review of International Affairs, Vol. 6, No. 4, December 2002 available at http://meria.idc.ac.il/journal/2002/issue4/jvol6no4in.html. 
comed in Greece and in several European capitals. ${ }^{11}$ Another striking development in November 2002 involved the introduction of the UN Plan, the so-called "Annan Plan," for the resolution of the Cyprus dispute. ${ }^{12}$ Considering that the Cyprus issue represented a major hurdle on the path of Turkey's full-membership, the Annan Plan, for the first time, raised a serious possibility concerning a mutually acceptable resolution of this long-standing conflict.

With these developments in the background, the decision reached at the EU Council's Copenhagen summit of December 2002 represented yet another step forward with respect to Turkey's membership aspirations. At the Copenhagen Summit, Turkey was given a date, namely December 2004, with the prospect of opening accession negotiations thereafter depending on the proper implementation of reforms in the interim period. Arguably, the outcome of the Copenhagen Summit could have been better from the Turkish point of view. ${ }^{13}$ If the EU had provided more powerful signals to Turkey, such as an earlier and definitive date for accession negotiations, this would have increased the resolve of the AKP government to confront the still powerful nationalist, "anti-EU coalition" in Turkey, and resolve the Cyprus dispute along the lines of the Annan Plan. ${ }^{14}$ Indeed, following the Copenhagen Summit, the AKP government made a U-turn in its policy towards Cyprus and the Annan Plan was effectively sidelined in the early months of 2003.

In retrospect, the Copenhagen Summit was also important in the sense that it forced Europe itself to think seriously about what Turkish membership entails. Up to that point, the prospect of Turkish membership, given the inherent difficulties in undertaking the kinds of reforms required, appeared to be a rather distant prospect that could safely be postponed into the indefinite future. Yet, the very pace of reforms

11. See Sean Michael Cox, "One Calorie Islam: Turkey's "Light Muslims" and the West," Turkish Policy Quarterly, Vol. 2, No. 1, Spring 2003, pp. 47-56; Suhnaz Yilmaz, “At the Gates of Europe,” The World Today, Vol. 59, No. 1, January 2003, pp. 9-11.

12. The Annan Plan, named for the UN Secretary-General, involves a reunification of Cyprus based on the principle of a single state comprised of two equal components in a dissoluble union, however, it offers considerable autonomy for both the Turkish and Greek communities on the island within the framework of a unitary state. The details of the Annan Plan on Cyprus are available at http:// www.mfa.gov.tr/grupa/ad/annan.doc. For a critical analysis of the Cyprus issue from the Turkish perspective also see, Hüseyin Bagci, "Turkish Reactions to the EU Approach," in Looking into the Future of Cyprus-EU Relations, Susanne Baier-Allen, ed., (Baden-Baden: Nomos, 1998), pp. 39-50.

13. For early assessments of the Copenhagen Summit, see Yilmaz, "At the Gates of Europe;" Mehmet Ugur, "Testing Times in EU-Turkey Relations: The Road to Copenhagen and Beyond," Journal of Southern Europe and the Balkans, Vol. 5, No. 2, August 2003, pp.165-183; and Bülent Gökay and Bülent Aras, "Turkey after Copenhagen: Walking a Tightrope," Journal of Southern Europe and the Balkans, Vol. 5, No. 2, August 2003, pp. 147-163.

14. The term anti-EU coalition has a specific meaning in the Turkish context. It refers to those elements both within and outside the state establishment who are opposed not to EU membership per se but the kind of political reforms demanded by the EU as a pre-condition for full-membership. Arguably, the military-security wing of the state and the radical nationalists, the MHP, have been the vocal elements in the anti-EU coalition. Such groups perceive the EU as a necessary threat to the unity and sovereignty of the Turkish state. 
in the post-Helsinki era clearly suggested that Turkish membership had to be confronted as a serious prospect.

\section{THE PARADOXICAL ROLE OF THE UNITED STATES: THE IMPORTANCE AND LIMITS OF AMERICAN INFLUENCE}

During the Cold War period, Turkey was a pivotal state for the United States. It was among the select group of countries with whom special strategic relationships had been developed in line with fundamental American economic and security interests. ${ }^{15}$ During the Cold War, the containment of the Soviet threat constituted the prime consideration. In the context of the late 1990s, Turkey's claim to a pivotal state status rested on its attractiveness as an "emerging market" and its willingness to counteract terrorism (particularly in the aftermath of 9/11). ${ }^{16}$

Washington increasingly realized the importance of Turkey as a key ally in its quest to deal with rising trans-national crime involving drug trafficking, money laundering, trafficking of human beings and, most important of all, terrorism. Indeed, Washington took on a strong stance against the Kurdistan Workers' Party (PKK), classifying it as a terrorist organization. The US approach in this respect deviated substantially from its European counterparts, the latter adopting a more ambiguous and qualified approach. The words of Mark Parris, the former US Ambassador to Turkey, aptly illustrate the importance of Turkey in a relationship that was fundamentally security-oriented. "From a security perspective, the military dimension of the relationship proved as important as during the Cold War. Turkish participation in peacekeeping actions in Somalia, Bosnia, Kosovo and Macedonia demonstrated to the Pentagon and White House planners Ankara's capabilities and readiness to shoulder responsibility as a 'security producing' nation." 17

The United States, right from the early stages, sought to link Turkey explicitly to the European integration process. The key objective here was to anchor Turkey firmly to the West by integrating it into its institutional settings. NATO was one of the key institutions; the EC/EU was another. The active promotion of Turkey's integra-

15. On the notion of pivotal state, see, Robert Chase, Emily Hill and Paul Kennedy, eds., The Pivotal States: A New Framework for US Foreign Policy in the Developing World (Norton and Co., 1998); and for a comprehensive recent analysis of Turkey as a pivotal state, from a predominantly American perspective, see, F. Stephen Larrabee and Ian O.Lesser, Turkish Foreign Policy in an Age of Uncertainty (Santa Monica,CA: RAND Publications, 2003).

16. On the broad contours of the US-Turkish relationship and its changing dimensions over time, see Kramer, A Changing Turkey and Morton Abramowitz, ed., Turkey's Transformation and American Policy (New York: The Century Foundation Press, 2000); and for a recent analysis, see, Morton Abramowitz, ed., The United States and Turkey: Allies in Need (New York: The Century Foundation Press, 2003). On the impact of different interest groups in shaping Turkish-American relations also see, Suhnaz Yilmaz, "Impact of Lobbies on Turkish-American Relations," in Turkish-American Relations: Past, Present and Future, Mustafa Aydin and Çagri Erhan, eds., (London: Routledge, 2004), pp. 181212.

17. See Mark R. Parris, "Starting Over: US-Turkish Relations in the Post-Iraq War Era," Turkish Policy Quarterly, Vol. 2, No. 1, Spring 2003, p. 7. 
tion into Europe also reflected a desire on the part of the US to share the burden of responsibility in creating a strong and stable ally in a critical region of the world. Indeed, the US' attitude and commitment to Turkey's integration process with the $\mathrm{EC} / \mathrm{EU}$ contrasted sharply with the far more ambiguous and lukewarm approach of the principal European states. One of the key reasons for this underlying difference is that Turkey's membership in the EU did not involve any explicit costs for the US.

The Europeans, on the other hand, had to take into account the potential costs of Turkish accession in terms of its impact on employment prospects, community-wide budgetary transfers, Common Agricultural Policy, the decision-making process and so on. ${ }^{18}$ Furthermore, the EU is a much more inward-oriented and much less security-oriented entity than the US. Consequently, it tends to view Turkey more as a security liability than as a security asset. This perception was based on the fear that the incorporation of Turkey would link the EU explicitly to a highly unstable part of the world and would import instability into the EU. ${ }^{19}$ Clearly, a major difference could be detected in the trans-Atlantic alliance well before the Iraqi War with the US, as a global power, putting much more emphasis on security and much less emphasis on the nature and quality of democracy than the EU. Hence, from an American perspective the security producing credentials of Turkey were of greater importance than its immediate democratic deficits, constituting a strong basis for rapid progress towards EU accession. ${ }^{20}$ In any case, it is fair to say that the American Administrations, right up to the Iraqi War, tended to view differences with Europe as being of marginal rather than of fundamental significance. Notably, from an American standpoint, differences pertaining to the nature of market economy and democracy were matters of detail, not constituting in any way issues of substantive divergence.

The US became increasingly active in promoting Turkey's membership aspirations for the EU from the late 1990s onwards. A number of concrete steps could be identified in this respect. Following the disappointments of the Luxembourg Summit, the Clinton administration provided active diplomatic support for Turkish initiatives. This support was, in part, instrumental in securing a favorable outcome for Turkey at the subsequent Helsinki Summit. ${ }^{21}$ In the aftermath of Helsinki, American support was also critical in terms of seeking a durable and mutually acceptable solution to the Cyprus dispute. ${ }^{22}$ Furthermore American support, through the International Mon-

18. This point was elaborated in detail by Sabri Sayari, "US and Turkey's EU Membership," Koç University, International Relations Seminar, December 2002.

19. Barry Buzan and Thomas Diez, "The European Union and Turkey," Survival, Vol. 41, No. 1, Spring 1999, pp. 41-57.

20. On the different perceptions of the US and the EU regarding Turkish accession, see Bruce Kuniholm, "Turkey's Accession to the European Union: Differences in European and US Attitudes, and Challenges for Turkey," Turkish Studies, Vol. 2, No. 1, Spring 2001, pp. 25-53.

21. See, Parris, "Starting Over" in this context.

22. For the active efforts and profound shuttle diplomacy of US State Department Special Coordinator for Cyprus Thomas Weston, and also the British envoy for Cyprus, Lord David Hannay, to convince all parties for a solution of the Cyprus dispute on the basis of the Annan Plan see, the press news of Cyprus News Agency between November 4 and December 22, 2002, available online at http:/ /www.hri.org/news/cyprus/cna/2002. 
etary Fund (IMF), was also important in Turkey's ability to come through the deepest economic crisis of the post-War era. ${ }^{23}$

The Copenhagen Summit of December 2002, however, clearly displayed the limits of American power in so far as decision-making regarding EU membership was concerned.

With the impending war in Iraq, the Bush Administration placed considerable diplomatic pressure in European capitals to generate an early accession date for Turkey. The fact that this backfired indicates that although American support is important, what ultimately matters is the ability of Turkey to undertake domestic economic and political reforms and to implement the Copenhagen criteria fully. In retrospect, one should also recognize that persistent American pressure for Turkey's EU membership had one important negative side effect. For a long time, it led significant elements of the state establishment in Turkey, notably the security and foreign policymaking elites, to assume that they could avoid implementing certain key components of Copenhagen criteria. Given Turkey's security importance and American support, they hoped to evade some elements of the Copenhagen criteria, such as the provision of cultural rights for the minorities (meaning the Kurds in the Turkish context), which they considered to constitute a threat to the unity of the nation-state. ${ }^{24}$

Rather paradoxically, therefore, strong American support for Turkey's EU membership tended to strengthen the "anti-EU coalition" in Turkey, meaning those who did not oppose EU membership per se but rather the political and economic conditions attached to EU membership. Indeed, such groups tended to view the US-IsraelTurkey axis as a natural basis for Turkish foreign policy and security interests and as a natural alternative to EU membership, which according to them was unlikely to be realized in any case given the conditions attached to such membership. ${ }^{25}$ Clearly, the position of these groups in Turkish politics was fundamentally shaken by the US-led war on Iraq and the strains in Turkish-American relations experienced in this context.

\section{CRITICAL TURNING POINTS: 9/11, IRAQ, AND THE TRANS-ATLANTIC RIFT}

The tragic events of $9 / 11$ and the fact that the United States had experienced severe acts of terrorism on its home territory for the first time in its recent history had a profound impact on the American psyche. The Bush Administration enjoyed the

23. The fact that the IMF was more supportive towards Turkey in 2001 compared with Argentina during the same year may be a reflection of the geo-political priorities of the United States. See, in this context, Ziya Önis, "Argentina, IMF and the Limits of Neo-Liberal Globalization. A Comparative Perspective," forthcoming in The Review of International Affairs, available online at http://home.ku.edu.tr/ $\sim$ zonis/publications.htm.

24. For a typical and eloquent exposition of this position, see the book by Ambassador Onur Öymen, Turkey's chief representative at NATO, Turkish Challenge: Turkey, Europe and the World Towards the 21 st Century (Cambridge: Rustem, 2000).

25. See Ihsan Dagi, "Competing Strategies for Turkey: Eurasianism or Europeanism?," Central Asia-Caucasus Institute Analyst, May 08/2002, online journal available at http://www.cacianalyst.org/ view_article.php?articleid=1189. 
support of the American public in developing a full front attack on international terrorism and the rogue states, notably in the Middle East, that constituted a potential home base for such activities.

While it was anticipated that after 9/11 the Bush Administration would pursue a hawkish domestic and international security-oriented agenda, the perceptions of the methods, means, and ends of these policies diverged sharply between the US and a number of its key allies in Europe and elsewhere. The differences reached a climax over the crisis in Iraq. The Bush Administration's quick resort to military action and unilateralism, which often meant by-passing multilateral channels and avoiding the employment of diplomatic pressures on a gradual step-by-step basis, received a particularly strong reaction. The war, while accentuating the trans-Atlantic rift, also created deep divisions within the EU itself. On the one hand, the core Franco-German alliance strongly opposed the American-led war on Iraq. On the other hand, a number of other EU members, notably Britain and Spain, as well as the new candidate countries from Eastern Europe led by Poland deviated from the Franco-German position and supported American military initiatives in Iraq.

The broader global dynamics of the post $9 / 11$ era exercised a deep influence on Turkey's fortunes regarding its prospects of EU membership. First of all, the increase in the intensity of support provided by the US for Turkish membership was clearly motivated by its immediate security priorities. In the long-run, the US favored a strengthening of the "Turkish model" of a secular democratic state, with a predominantly Muslim population, as a model for the rest of the Arab Middle East. In the short-run, its prime concern was to ensure the full cooperation of Turkey in its quest to overthrow the Saddam regime. The cooperation of Turkey meant the use of Turkish territory and air space as a key base of attack on Iraq from the north. Hence, a direct parallel could be formulated between the impending war, which looked increasingly inevitable by the final months of 2002 and the persistent diplomatic support provided by the US. This support became particularly evident with the disclosure of the Annan Plan in November 2002 and the strong pressures brought upon the European leaders by the Bush Administration on the eve of the Copenhagen Summit of 2002.

With these developments in the background, the US Administration considered Turkey's full cooperation for its war efforts as inevitable. With its crisis-ridden economy, Turkey was dependent on direct and indirect financial support from the United States. Furthermore, Turkey's foreign policy initiatives in such diverse areas as EU membership, the Cyprus question, or the Baku-Ceyhan pipeline project were dependent on American support. Yet, such assessments by Washington failed to take into account the frustration of the Turks regarding the political and economic burden and unfulfilled promises of the Gulf War of 1991, the competing views among the key political actors in Turkey, and the divisions within the rather inexperienced AKP government itself. Moreover, Northern Iraq has constituted a persistent trouble spot in the USTurkish strategic partnership.

The failure of the Turkish Parliament to ratify a decision involving the deployment of American troops in Turkish territory on March 1, 2003, thus, caused a major shock among the pro-Turkish Bush Administration and the defense establishment in 
Washington. One has to emphasize that it was a rather close decision with an internal rift in the AKP tilting the balance towards a negative vote. The dynamics underlying this decision, involving such issues as whether the new AKP government presented its case properly in the Parliament to the role of the military in this decision, have already been widely discussed. ${ }^{26}$ What is important for our purposes is that the rather unexpected decision of the Turkish Parliament caused a major stalemate in TurkishAmerican relations.

\section{THE TURKISH-US TROUBLE OVER IRAQ: UNINTENDED DOMESTIC AND EUROPEAN CONSEQUENCES}

In the post-Copenhagen period, the most pressing issue on Turkey's foreign policy agenda has been the war in Iraq. While Turkey strongly supported clearing the region of weapons of mass destruction and the fight against terrorism, it was also very uneasy about the repercussions of the military operation in Iraq. Both civilian authorities and the military-security elite were concerned that a long-lasting transition period and chaos in the aftermath of the war might cause broader regional instability and an increased wave of terror.

Turkey had suffered considerable economic losses in the aftermath of the Gulf War of 1991. Furthermore, Turkey has been exposed to a serious problem of massive flow of refugees from Northern Iraq. Perhaps most significantly, the Gulf War has helped to create a political vacuum in Northern Iraq that rendered the task of fighting the PKK even more difficult in the context of the 1990s. ${ }^{27}$ The Turkish government was very anxious about the recurrence of similar problems.

Turkey has been particularly keen on protecting the territorial integrity of Iraq due to its apprehensions regarding the establishment of an independent or a federated Kurdish state in Northern Iraq. Turks are anxious that the establishment of a neighboring Iraqi Kurdish state might cause a revival of the past problems and might lead to more demands for autonomy among the approximately 12 million Kurds living in Turkey. An additional concern is that a wealthy autonomous Kurdish state, in control of the rich oil reserves of the Mosul-Kirkuk region, could lend its support to the cause of Kurds in Turkey and emerge as a major destabilizing factor in this area. Syria and Iran, which have substantial Kurdish minorities of their own, are also keen on protecting the territorial integrity of Iraq. As a counterbalancing factor to the Kurds in Iraq, the fate of the Iraqi Turkomans and the protection of their rights has been a major concern for the Turkish government.

26. For a detailed discussion of these issues, see Philip Robins, "Confusion at Home, Confusion Abroad: Turkey between Copenhagen and Iraq," International Affairs, Vol.79, No. 3, May 2003, pp. 547-566.

27. On Northern Iraq as a trouble spot in Turkish-American relations and on the negative consequences of the Gulf War from a Turkish perspective, see, Kemal Kirisçi, "U.S-Turkish Relations: New Uncertainties in a Renewed Partnership," in Barry Rubin and Kemal Kirisçi, eds., Turkey in World Politics: An Emerging Multiregional Power (Boulder, Co.: Lynne Rienner Publishers, 2001), pp. 129149; and Philip Robins, Suits and Uniforms: Turkish Foreign Policy since the Cold War (London: C. Hurst\&Co., 2003). 
Despite all these problems, particularly during the AKP leader Recep Tayyip Erdogan's visit to Washington on the eve of the Copenhagen Summit, the Turkish government sent strong signals to the US regarding future collaboration over Iraq in exchange for ardent American support for Turkey's European quest. After the immediate disappointment associated with the Copenhagen decision and the failure to achieve a UN mandate for the military operation in Iraq, however, the climate started to change. Nevertheless, in Washington and European capitals it was almost taken for granted that Turkey would yield to the demands of its indispensable ally. Thus, as the result of a series of miscalculations and diplomatic blunders on both sides, after a prolonged period of bargaining over financial, political and logistical matters when the Turkish parliament refused to grant US troops transit rights, it came as a total surprise. Following a heated debate in the Turkish Grand National Assembly, the resolution failed by a margin of only three votes. Consequently, the deeply frustrated Bush Administration had to scrap its plans to send possibly as many as 62,000 troops through Turkey in order to open a second front in Northern Iraq.

Ironically, the democratization that the US has been trying to impose from above in Iraq and the rest of the Middle East came at a rather high price for Washington this time when the Turkish government failed to get parliamentary backing for a deeply unpopular war among the Turkish public. This decision was also costly for the Turks. Turkey not only lost a massive US financial compensation package worth $\$ 6$ billion and the possibility of having more influence in shaping the future of Northern Iraq, but these developments also greatly strained Turkish-American relations. While after another impasse Turkey finally granted US over-flight rights, the relations and trust among the parties have already been significantly damaged.

The post-war structuring of Iraq and particularly the fate of Northern Iraq emerges as a particularly thorny issue. US officials made numerous remarks indicating their opposition to an "uncoordinated" movement of Turkish troops into Northern Iraq. They were wary that any massive Turkish movement across the border in response to Kurdish attempts to establish control over Mosul and Kirkuk could inflame tensions among Turks and Iraqi Kurds. The European Commission and a number of individual nations have also warned Turkey that sending troops to Northern Iraq would complicate its EU membership process. In response to these warnings, the Turkish General Staff made an announcement underscoring that Turkey has no territorial intentions in Iraq. It stated that while Turkey reserves its right to move troops if its national security is threatened, it intends to have a limited and coordinated presence across the border for humanitarian purposes and prevention of terrorist activities. ${ }^{28}$ Hence, when

28. The US and Britain strictly warned Turkey that an intervention in northern Iraq is unacceptable and unfavorable. See, "Bush'tan Sert Mektup," ["Harsh Letter from Bush”], Hürriyet July 24, 2003 and "Blair: K.Irak'a müdahale kabul edilemez," ["Blair: Intervention in Iraq is Unacceptable,"] Hürriyet, July 24, 2003. The EU Commission also declared that intervention of Turkish army to northern Iraq would negatively affect Turkey's membership process. See "AB'den bir Uyari Daha," ["Another Warning from the EU"], Hürriyet, July 24, 2003. For the briefing of the Turkish General Staff that stated Turkey did not consider an intervention as necessary other than as a need for a reinforcement for humanitarian and security concerns, 
the US kept the movements of Kurdish fighters under control, responding to the Turkish sensitivities, and the Turks refrained from an adventurous move, the disaster scenario of unilateral Turkish intervention in Northern Iraq was aptly averted.

There were some diplomatic attempts to mend the ties. The humiliating US arrest, on July 4, 2003, of 11 Turkish special forces in Sulaimaniyya for allegedly conspiring to assassinate the Kurdish governor of Mosul, however, clearly indicated the precarious nature of relations and the lack of trust among the parties. ${ }^{29}$ As a result of these developments, Turkish-American relations reached their lowest ebb in years giving way to a mutual questioning of the meaning and viability of the concept of Turkish-American "strategic partnership."

These international developments also had unintended consequences for Turkey's domestic politics and its relations with Europe. The developments concerning Iraq, which set the Turkish-American relations on a troubled path, ironically brought Turkey closer to the EU. First of all, they enabled the political leadership in Turkey to give impetus to the reform process by weakening the anti-EU coalition and underscoring the importance of Turkey's European orientation. Second, they indicated that the democratic system worked in Turkey even under heavy US pressure. Finally, they made it harder to justify the arguments often heard in policy circles, particularly in France and Germany, that Turkey is too pro-American and could serve as a US "Trojan horse" if it enters the EU.

Furthermore, the "anti-EU coalition" has been negatively affected by the adverse development in Turkish-American relations. With the US effectively based in Iraq, the ability of the Turkish military and security establishment to develop an independent line of policy towards Northern Iraq has largely disappeared. Moreover, the security-oriented Turkey-US-Israel triangle, which was perceived as the natural alternative to deep integration with the EU by "anti-EU coalition," came under serious challenge. Following the deterioration of relations with the US, assuming that the EU alternative was also discarded, the result would have been total isolation. Given this background, the AKP has been able to press ahead with EU related reforms at full speed during the course of 2003 and notably during the summer of 2003.

The Seventh Adjustment Package to the EU's Copenhagen Criteria was ratified by the Turkish Parliament and went into effect on August 8, 2003. The Seventh Package represents a major turning point in Turkey-EU relations because, for the first time, the political leadership in Turkey found itself in a position to tackle the thorny question of civil-military relations. The status of the National Security Council (NSC) as well as the civil-military balance within the Council also came under increasing scrutiny. The reform package significantly curbs the role of the military in politics, at least in principle, through measures including limiting the executive powers and areas of responsibility of the NSC, increasing the civilian presence on the NSC, and bring- 
ing military expenditures (which were not publicly audited in the past) under the inspection of the Court of Accounts. ${ }^{30}$ These rather dramatic reforms were widely welcomed in European capitals.

The Turkish Parliament also introduced a new series of constitutional amendments on May 7, 2004. This new reform package indicated the firm commitment of Turkey towards compliance with the Copenhagen political criteria. In fact, a number of the amendments address the specific issues mentioned in the Commission's Regular Report and in the Conclusions of the Brussels European Council of December 2003. ${ }^{31}$ The new provisions under this reform package cover significant issues ranging from judicial reform, freedom of the press, civil-military relations to gender equality. Some of the changes, such as the abolition of the State Security Courts (DGM) ${ }^{32}$ and the withdrawal of the representative of the National Security Council on the Higher Education Board, are particularly important.

While Turkey has made a giant step towards fulfilling the Copenhagen criteria by introducing key changes through legislation, implementing them in practice will be essential and still serves as the real challenge. There is evidence that the militarysecurity establishment and their counterparts in civilian politics are rather unhappy about some of these changes. ${ }^{33}$ Hence, in spite of signs of serious progress, there is still quite a distance to travel in terms of Turkey's ability to satisfy Copenhagen criteria in practice. The "anti-EU coalition" is on the defensive in Turkey following the chain of events that started with the Helsinki Summit followed by the Copenhagen Summit and finally the Iraq War. Moreover, the military-security establishment is

30. Soner Çagatay, "European Union Reforms Diminish the Role of the Turkish Military: Ankara knocking on Brussels' Door," Analysis of Near Policy from the Washington Institute, Policywatch No. 781; “7. Paket Devrimi," ["Revolutionary 7th Reform Package"], Hürriyet, July 3, 2003. On the evolution of the national security culture and the recently diminishing role of the military in politics in Turkey also see, Ali Karaosmanoglu, "The Evolution of the National Security Culture and Military in Turkey,” Journal of International Affairs, Vol. 54, No.1, Fall 2000, pp.199-216.

31. European Council, Conclusions of the Brussels European Council, December 2003, http:// europa.eu.int/comm/councils/bx20031212/index_e htm (European Council website).

32. These were special state security courts, which were created for terrorism and treason cases.

33. The military officials are primarily concerned about the decision to convert the NSC to a purely advisory institution and render military expenditures openly accountable to the political process. See, in this context, "7. uyum paketine kita dur!," ["Halt to the Seventh Adjustment Package!"], Radikal, July 19,2003 . The chief adviser to the secretary-general of the NSC opposed the new regulations in the package, and claimed that they effectively abolish the executive role of the NSC altogether. See, "7. Uyum Paketine MGK Tepkisi," ["NSC's Reaction to the 7th Adjustment Package"], Hürriyet, July 28, 2003. Indeed, some of the concerns of the military have been taken into account by modifying the Seventh Adjustment Package. For example, military expenditures will be rendered accountable, but only partially, in the sense that the auditing process will be conducted in secrecy by the Court of Accounts. See, “7. Uyum Paketi Tamam," ["OK to the 7th Adjustment Package,"], Hürriyet, July 30, 2003, in this respect. Furthermore, the AKP government was forced to compromise by delaying its decision to appoint a civilian person for the post of the NSC Secretary-General by one year. See, "MGK Genel Sekreteri yine asker," ["General Secretary of the NSC is from the Military Again,"], Hürriyet, August 3, 2003, and "Sivil MGK 3 Nedene Takildi," ["Three Obstacles to a Civilian NSC"], Hürriyet, August 4, 2003. 
also undergoing a learning process and has been progressively shedding off its hardliner position by adopting a more favorable pro-European stance. Yet, the resilience of the nationalist or the anti-EU coalition should not be underestimated, and particularly the Kurdish and Cyprus issues should continue to be approached with considerable caution and reservations. To overcome this resilience it's crucial that the EU send more clear signals to Turkey regarding its prospects for full membership. The December 2004 decision to start accession negotiations has been an important step in this direction.

In immediate terms, the rather surprising March 1, 2003 decision against deploying US forces helped to move Turkey closer to the position of the core FrancoGerman alliance that naturally constituted the dominant force within the EU bloc. This situation constituted an interesting and paradoxical development in the sense that the core Franco-German alliance was less receptive to future Turkish membership, whereas countries like Britain and Spain, that favored a looser pattern of integration in the EU, provided stronger support for Turkish membership. What was striking in this context was that members of the EU that supported the American initiatives in Iraq were also the countries that felt at greater ease with potential Turkish membership.

The developments in Turkish domestic politics during the early months of 2003 have brought Turkey rather unintentionally and unexpectedly closer to the core EU position. In retrospect, Turkey was also already moving closer to the EU following the processes initiated in the Helsinki and then the Copenhagen Summits. Yet, the course of events instigated by the US military initiatives in Iraq and the impetus given to the reform process in the domestic scene have clearly helped to accelerate this process.

\section{PROSPECTS FOR THE RESTORATION OF THE TRIANGLE: THE DELICATE BALANCE AND THE CHALLENGES AHEAD}

Despite the Iraq War's deepening effect on the trans-Atlantic rift and the major setback in Turkish-American relations, there is room for optimism about the reconstitution of the Turkey-EU-US triangle and this triangle could rest on more secure foundations as Turkey moves closer to EU membership. Our optimism, however, has to be qualified by the fact that various things may go wrong, upsetting the emergence of such a benign equilibrium.

Over the course of the past year, particularly due to the differences over the developments in Iraq, the US' relations have been seriously damaged, not only with Turkey but also with a number of its key European allies. This sparked an unprecedented debate both within the US and Europe about the changing structure and the future course of trans-Atlantic relations.

Some scholars, like Robert Kagan, argue that a serious power and ideological gap has emerged between the US and Europe. Thus, Kagan claims that Europe "is entering a post-historical paradise of peace and relative prosperity, the realization of Immanuel Kant's 'perpetual peace.' Meanwhile, the United States remains mired in 
history, exercising power in an anarchic Hobbesian world where international laws and rules are unreliable, and where true security and the defense and the promotion of a liberal order still depend on the possession and the use of military might." ${ }^{\prime 34}$ Consequently, he concludes "That's why on major international and strategic questions today, Americans are from Mars and Europeans are from Venus" and these differences are likely to endure. ${ }^{35}$

There are others, like Philip Gordon, who present a more optimistic view, stressing that in spite of their differences, core American and European values and interests have not diverged and these differences are mainly the result of a drastic policy shift in Washington under the Bush Administration. ${ }^{36}$ Ivo Daalder, pointing out that the relations have reached a turning point signaling "the effective end of Atlanticism" argues that, "An effort to forge complementary and mutually supportive policies to rebuild Iraq and stabilize and reform the Middle East may solidify the faltering relationship, while a determination by the US to go it alone may push it over the edge." ${ }^{37}$ Thus, within this context, the restoration of the damaged relations within the TurkeyUS-EU triangle gains particular importance.

There are already mitigating factors and promising signs in this respect. First of all, the EU is not a monolithic entity. There has been serious support for the US position from many old and new members of the enlarged European Union. Second, while the core Franco-German Alliance opposed the war, at the same time, it condemned the Saddam regime and is clearly interested in a peaceful reconstruction of Iraq in the post-war context. Clearly, the kind of benign scenario that we present in this article depends critically on developments within American domestic politics itself. From an American perspective, there is increasing recognition that, regardless of the economic and military might of the United States, unilateralism as a strategy is unlikely to succeed in achieving long-term peace and stability in the volatile Middle East. Hence as the financial and human cost of occupation becomes more evident, there are increasing pressures on the Bush Administration to seek international cooperation in the post-war reconstruction of Iraq. The UN Security Council's unanimously passed October 16, 2003 resolution for the creation of a multinational peacekeeping force for Iraq is an important step in this direction.

As time passed, a change of attitude was also evident in the US approach to Turkey, resulting in a mellowing of the tense atmosphere prevailing in the immediate aftermath of the Iraq War. The US request for Turkish participation in the interna-

34. Kagan softens this position slightly towards the conclusion of his book Paradise and Power, by stating that "although it is difficult to foresee a closing of the Atlantic gap between American and European perceptions of the world, the gap may be more manageable than it currently appears. There need be no "clash of civilizations" within what used to be called the West. The task, for both Europe and the Americans, is to readjust to the new reality of American hegemony." Robert Kagan, Paradise and Power: America and Europe in the New World Order (London:Atlantic Books, 2003), pp. 3, 97.

35. Kagan, Paradise and Power.

36. Philip H. Gordon, "Bridging the Atlantic Divide," Foreign Affairs, Vol. 82, No.1, January/ February 2003, p.74.

37. Ivo H. Daalder, “The End of Atlanticism," Survival, Vol.45, No.2, Summer 2003, pp. 147-166. 
tional peacekeeping operation in Iraq reflected a change in this direction. The Turkish forces have already played an important role in the peacekeeping operations in Somalia, the Balkans, and most recently in Afghanistan. In June 2002, Turkey took over the command of ISAF (the International Security Assistance Force) in Afghanistan for a period of nine months. The Turkish Parliament's October 2003 vote that ratified the decision to send a peacekeeping force to Iraq in line with US demands was an important step in terms of repairing US-Turkish relations. In order to assist in restoring the peace and stability in Iraq, to strengthen its influence in shaping the future of this region, and to mend its ties with the US, the Turkish government accepted to contribute troops to the peace-keeping operations in Iraq. This time, however, the Iraqi Governing Council ardently opposed admitting troops from Turkey, placing Washington in a rather awkward situation. Even if eventually Turkish troops are not deployed in Iraq, Turkey's goodwill gesture has made a positive impact in Washington.

At this stage, for the enhancement of Turkish-American relations the most critical issue is to restore the mutual trust between the two parties. On the one hand, given the significant American support for Turkey's initiatives on the European front, the Bush Administration felt let down during the War in Iraq. On the other hand, in addition to the anti-war sentiment among the Turkish public during the crisis in Iraq, both civilian and military elites as well as the wider public in Turkey have been uncertain about US motives in the region, particularly concerning Northern Iraq. Despite their differences on other issues, they are all quite suspicious towards the US claim that it will support a united Iraq, hence, resisting the eventual formation of an independent or a federated Kurdish state in the north.

A recent Pew study indicates that while the popularity of the US in Turkey was $52 \%$ in 2000 , this popularity has dropped to $30 \%$ in 2002 , and to a meager $12 \%$ in March 2003. Moreover, in a survey concerning the US image in the aftermath of the Iraqi war, $83 \%$ of the respondents replied that they have a negative image of the US. ${ }^{38}$ This is an alarmingly high percentage for a country like Turkey that has traditionally been a staunch ally of the US and has a generally pro-American public opinion. At this stage, it is essential to address this collateral damage to trust on both sides. As suggested by Mark Parris, it is critical "to reestablish the reservoirs of trust and mutual accommodation, and the means of effective communication, that have enabled Turks and Americans to meet so successfully the challenges we have faced together over more than sixty years of friendship and alliance. As a starting point, leaders on both sides can have no higher priority than that." ${ }^{39}$

What else can the Turkish side do to reconstitute the triangle? First of all, it should continue promoting EU related reforms at the fastest rate possible and strengthen its economy. Moreover, it needs to pursue a pro-active policy in tackling the Cyprus dispute along the lines of a revived Annan Plan. While it had its shortcomings and was not entirely satisfying for either side, the Annan Plan presented a serious opportunity

38. Quoted in "ABD Türkiye'ye Askeri Tehdit," ["US as a Military Threat to Turkey”], Hürriyet, June 4, 2003.

39. Parris, "Starting Over," p. 7. 
for the long-lasting Cyprus dispute to be resolved within the European context. Due to the rejection of the plan by the Greek Cypriot side, however, as stated by the UN's Alvaro de Soto, "A unique and historic chance to resolve the Cyprus problem has been missed." ${ }^{40}$ After the political will and determination displayed by the Turkish and Turkish Cypriot governments for the reunification of the island, the pressure on Turkey regarding the Cyprus issue is mitigated. Greek Cypriots, nevertheless, hold a strong trump card as a member of the EU. For instance, they are already pressuring Turkey for recognition and for the extension of Turkey's Customs Union with the EU to the Greek Cypriot part of Cyprus. Once the accession negotiations start, the Greek Cypriot pressure on Turkey will also increase. By offering asymmetric incentives and by admitting the Greek half of Cyprus as a fully fledged member state, despite its rejection of the unification plan, the EU found itself importing an old conflict, which is not limited only to Cyprus but is linked to Greece and Turkey as well. To the dismay of Brussels, the fortified Green Line dividing the two parts of Cyprus has now become an external EU border. In the difficult path towards reaching a sustainable solution to the Cyprus problem within the EU context, the US also has a critical role to play as a balancing factor, once again underscoring the importance of improving Turkey's relations with the US.

Finally, regardless of the merits of the disagreement among the US, a number of its European allies, and Turkey concerning the war in Iraq, in its aftermath, ensuring a peaceful and stable Iraq is in the interest of all concerned. Post-conflict nationbuilding is an extremely complicated and complex process. While the US succeeded in achieving a swift military victory through its unilateralist approach, winning the peace and creating long-lasting stability will be the real challenge. As the almost daily attacks on the coalition forces and the wave of terrorist acts (such as the attacks on the Jordanian Embassy, oil pipelines, and the UN Headquarters in Baghdad) indicate, the post-war restructuring of Iraq will indeed be a very difficult task. In tackling this challenge, in addition to involving Iraqis themselves genuinely and substantially in the governing process, a multilateralist approach will be much more fruitful. Within this context, enhancing collaboration in all dimensions of the Turkey-EU-US triangle will be particularly helpful.

\section{CONCLUDING OBSERVATIONS}

The Turkish leaders have been walking on a diplomatic tight-rope since the beginning of the crisis in Iraq and it is essential that they strike a delicate balance between Turkey's own security interests, the necessities of its close alliance with the US, its European orientation and the public demands. The rapidly deepening transAtlantic fault-line between the United States and a number of key European countries presents an additional problem. Since all of these elements seem to be pulling Turkey in different directions, reconciling the differences will be an extremely challenging

40. “Exit Poll: Cyprus Reunification Plan to Fail,” April 24, 2004, http://cnn.worldnews.com. 
but crucial task.

In a recent article in the Turkish daily Radikal, a well-known commentator on Turkey-EU relations, Cengiz Aktar, argued that Turkey has won great prestige in the international arena by not sending soldiers to Iraq by the March 1 decision. Thus, he concluded "From now on we [the Turks] should save ourselves from our obsession with the US and direct our course towards the EU." ${ }^{41}$ However, such a one-sided approach that relies single-mindedly on Turkey's European orientation, turning one's back to the US completely in the process, is not likely to constitute a prudent strategy for Turkey.

Despite the progress by setting the date for the opening of accession negotiations, there is still considerable uncertainty regarding Turkey's thorny path towards full membership. An isolated Turkey without American backing may find itself confronted with further delays in its quest to become an EU member. The US influence may also ultimately be critical in resolving the Cyprus dispute, which constitutes the single most important hurdle on Turkey's path to EU membership. Furthermore, failure to reconstitute the strategic relationship with the US (given that it is likely to maintain a direct presence in the region for some time) may prevent Turkey from playing an active role in the reconstruction of Iraq in particular and shaping developments in the broader Middle East in general. Thus, while giving priority to its European quest, it is also critical for Turkey to mend its ties with the US.

At the same time, the security-based strategy which depends solely on the alliance with the United States and its diplomatic influence on Europe will not generate the desired outcome for Turkey - as the Copenhagen Summit aptly illustrated unless there is the will to undertake and properly implement the required reforms. In other words, contrary to the thinking of some, American help could not act as a substitute for reforms in the context of Turkey-EU relations.

The future of the Turkey-EU-US triangle is likely to be characterized by a mix of continuity and transformation at the same time. It is likely to display continuity in the sense that from the Turkish perspective, a single-minded emphasis on developing relations either with the US or EU will not be a viable approach. Indeed, one of our central claims is that developing close relations with one of these major entities is likely to have positive payoffs in terms of deepening relations with the other major bloc. The extent and nature of this impact, however, will also be determined by the delicate dynamics of the trans-Atlantic relations itself. Even though the Bush Administration has gained a mandate for a second term, there are both domestic and external constraints that limit the degree of unilateral action with respect to American foreign policy. The policies of the Bush Administration during its second term, particularly whether it would continue to pursue hawkish and unilateralist policies in the Middle East or whether it would have a more multilateralist approach, would have a significant impact on the bilateral relations as well as the future of the Turkey-EU-US triangle.

41. "Rota Avrupa'ya Dönmeli," [“Turkey Should Direct its Course to Europe”], Radikal, August 7, 2003. 


\section{$284 \star$ MIDDLE EAST JOURNAL}

The very nature of the triangle is also likely to experience a significant transformation. Deepening relations with the EU require a parallel deepening of the reform process. American support per se is not likely to generate smooth progress towards EU membership in the absence of radical commitment and implementation of economic and political reforms. Deepening relations with the EU, in turn, will offer Turkey the prospect of reconstituting its relations with the United States, which will be more in line with its national interests and which will also enable it to play a more constructive role in the broader Middle East as a benign regional power.

The historic decision of the European Council on December 17, 2004 to open up accession negotiations with Turkey in October 2005 constitutes yet another crucial step in bringing Turkey closer to the European Union. This decision will continue to swing the pendulum further in the direction of closer relations with the EU and a certain distancing away from the United States, a process that was already under way following the rift that emerged between Turkey and the US during the Iraq War. At the same time, however, it is important for Turkish policy-makers to maintain a balanced foreign policy stance with the United States. An immediate challenge in this context is the resolution of the Cyprus dispute, an issue of critical importance on Turkey's path to EU membership. Diplomatic support and pressure on the part of the US on the key actors involved could have a crucial bearing in this respect. Whether the US is willing to perform the active role that it once assumed - regarding Turkey's membership of the EU, and the resolution of the Cyprus dispute, given the rift that has emerged between Turkey and the US in the post-Iraq War era - is an issue of major practical relevance. It is quite likely that the US may adopt a more passive stance in this respect in the present conjuncture and it is, therefore, important for the Turkish policy-making elite to continue the process of reconstructing a balanced relationship between European Turkey and the United States.

It is a critical time when there are new road maps emerging for shaping the future of the Middle East, Eurasia, and particularly Trans-Atlantic relations. What is really needed is to assess critically the aspects of continuity and radical transformation in the international context and to try to strike a delicate balance in the Turkey-EUUS triangle. On the Turkish side, there should be a simultaneous and pro-active effort to enhance the relations with both sides, not at the expense of each other, but in a mutually re-enforcing way. At the same time, it is also essential for Turkey's American and European allies to realize that it would be too costly for either side to alienate and isolate Turkey. Furthermore, Turkey could play a significant role as a predominantly Muslim, yet secular country in a volatile region vital for both American and European interests. Indeed, as a member of a broader entity such as the EU, rather than an isolated middle power in itself, and acting in cooperation with the United States, Turkey is more likely to play a constructive role in this respect. 